\title{
Does Pancasila Support Religious Pluralism in Indonesia in Postmodern Era
}

\author{
Philip Suciadi Chia' ${ }^{1)}$, Frederich Oscar Lontoh $^{2)}$, Surja Permana ${ }^{3)}$, Juanda $^{4)}$, \\ Daniel Ari Wibowo ${ }^{5}$ \\ 1) Southern Baptist Theological Seminary - Kentucky USA \\ E-mail:pchia275@students.sbts.edu \\ 2) Evangelical Theological Seminary of Indonesia - Surabaya \\ E-mail:oscarlontoh@sttii-surabaya.ac.id \\ 3) Evangelical Theological Seminary of Indonesia - Surabaya \\ E-mail: surjapermana@sttii-surabaya.ac.id \\ 4) Evangelical Theological Seminary of Indonesia - Surabaya \\ E-mail: juanda@sttii-surabaya.ac.id \\ ${ }^{5)}$ Evangelical Theological Seminary of Indonesia - Surabaya \\ E-mail:ariwibowodaniel@sttii-surabaya.ac.id
}

\begin{abstract}
Since Indonesia is also one of the most diverse societies in the world such as there are over three hundred different ethnic groups in Indonesia, each with its own cultural identity, and more than two hundred and fifty distinct languages are spoken, then Pancasila is created as philosophic fundamentals of the state to supports the diversity in Indonesia. Pancasila (from a Sankrit word: panca: five and sila: principle) consists of five principles that are interrelated and inseparable to generate unity in diversity (bhinnekatunggalika). In this paper, I will argue that Pancasila promotesand facilitates religious diversity although religious culture in Indonesia does not promote religious pluralism.
\end{abstract}

Keywords: Religious Pluralism, Postmodernism and Indonesia.

\section{INTRODUCTION}

Indonesia is the fourth of the most populous nations in the world as of February 2019. The population of Indonesia is 268.074.600 people and Java island is one of the most densely populated areas in the world. Indonesia is also one of the most diverse societies in the world. Hildred Geertz captured the diversity of Indonesian society as follows:

There are over three hundred different ethnic groups in Indonesia, each with its own cultural identity, and more than two hundred and fifty distinct languages are spoken nearly all the important world religions are represented, in addition to a wide range of indigenous ones.

This diversity is also supported by Pancasila which is Indonesian foundational theory and ideology. This paper, thus, will attempt to answer if Pancasila supports religious pluralism in Indonesia although
Indonesia is the largest Muslim country in the world. The answer will be sought by examining a) Indonesia: its diversity, Pancasila, the relationship between religious diversity with Pancasila; b) religious pluralism in Postmodern era. After studying these issues, the relationship between religious unity in Pancasila with religious pluralism will be discussed.

\section{DIVERSITY IN INDONESIA}

This part will discuss the diversity in Indonesia both in population (ethnicity) and religions. 


\section{DIVERSITY OF POPULATION IN INDONESIA}

The population of Indonesia can be divided into two major groups: in the western region most of the people are from the Malay ethnicity while in the eastern region there are the Papuans originating from the Melanesian Islands. Indonesia also recognizes specific ethnic groups that come from a certain province/area and have specific language for example the Javanese from Central or East Java, the Sundanese from West Java or the Batak ethnicity from North Sumatra. In addition, there are also minority ethnicities derived from Chinese, Indian and Arabic descendants. These people travelled as merchants through trade exchange since the 8th century $\mathrm{BC}$ and migrated to Indonesia. Approximately 3\% of the population is from Chinese ethnicity, although the exact percentage is not known as the last ethnicity census was held in the 1930s.

\section{DIVERSITY OF RELIGIONS IN INDONESIA}

Islam is the major religion of $85.2 \%$ of the population, designating Indonesia as the largest Moslem country in the world. The remaining population consists of Protestants (8.9\%); Catholics (3\%); Hindus (1.8\%); Buddhists $(0.8 \%)$ and other religion $(0.3 \%)$. Among these five known religions, Hindus and Buddhists are polytheism religions. The rests are monotheism.

As we have mentioned above that trade has fundamentally shaped Indonesian history both population and religions. Immigration from India, China, Portugal, Arab and Dutch has contributed to the diversity of religion and culture in Indonesia. Hinduism and Buddhism, for instance, were brought to Indonesia around second and fourth century by Indian merchants when they arrived in Sumatra, Java and Sulawesi Island. Kutai, Sriwijaya, Majapahit and Sailendra kingdoms were influenced by these religions. Borobudur is Buddhist temple, for example, was built by Sailendra kingdom at the same time with Hindu monument Prambanan that was built by Sanjaya Dynasty. Then, Islam came to Indonesia in thirteenth C.E and spread out through the West coast of Sumatra and then developed in East Java. Demak, Pajang, Mataram and Banten kingdoms were influenced by Islam. In sixteenth C.E, Catholic was brought by the Portuguese to Flores. In the same century, the Dutch introduced Protestant and spread out in Sulawesi, Nusa Tenggara, Papua and Kalimantan. In summary, Indonesia is multireligions country historically.

\section{PANCASILA}

Indonesia is a democratic country that applies a presidential system and Pancasila is the soul of the Indonesian democracy. Pancasila is the philosophic fundamentals of the state. Pancasila (from a Sankrit word: panca: five and sila: principle) consists of five principles that are interrelated and inseparable to generate unity in diversity (bhinnekatunggalika), namely:

\section{The belief in one God}

\section{A just and civilized humanism}

\section{Unity of Indonesia}

4. Democratic citizenship lead by wise guidance born of representative consultation

5. Social just for all the people of Indonesia

After proposing Pancasila, Soekarno, the first president of Indonesia, summarized Pancasila into three (trisila): a) Socionationalism (embracing Nationalism and Internationalism), b) Socio-democracy (consisting of the principles of Democracy and Social Welfare), and c) the Belief in God (Spiritual aspect).

The Relationship between Pancasila and Religions in Indonesia In this part, I will argue that Pancasila was made upon the diversity in Indonesia. Thus, Pancasila supports the diversity of religions in Indonesia. I will present two main arguments. First, the founder of Pancasila and, the second, the Pancasila itself from a) the explanation of the first principle (belief in one God), b) bhinnekatunggalikaas the purpose of Pancasila and c) the early history of Pancasila. 


\section{PRESIDENT SOEKARNO' BACKGROUND}

Soekarno' Family.Sukarno was born on June 6, 1901, in Surabaya, and was given the name KusnoSosrodihardjo. His parents later renamed him Sukarno after he survived a serious illness. Sukarno's father was RadenSoekemiSosrodihardjo, a Muslim aristocrat and school teacher from Java. His mother Ida AyuNyoman Rai was a Hindu of the Brahmin caste from Singaraja Kingdom (Buleleg) Bali. He learned about Islam from his father (kejawen) and teosofi. His mother taught him Hinduism and Buddhism. From his grandparents, he was introduced to Java culture, animism and mysticism. Sarinah, his nanny, taught him humanism: how to love other human being. In short, Soekarno lived in the diversity of religions since he was young.

Soekarno' Education. Alfian notes that there were three major elements of thought that influenced Soekarno' mind. First, the school of thought arising from the fundamental values of his nation's culture, especially Javanese culture. Second, the trend of thought developed by Western Socialist thinkers, including Karl Marx (1818-1883). Third, Soekarno was influenced by Tjokroaminoto and K. $\mathrm{H}$. Ahmad Dahlan' speeches about the nationality movements that were enveloped by Islamic identity. He was also interested in the current of thought formulated by the thinkers of Islamic modernism such as Muhammad 'Abduh and Jamal al-Din al-Afghani. The result of Soekarno' synthesizing of ideas can be seen, for example, in his long article entitled "Nasionalisme, Islamisme and Marxisme" in which he states that "these three waves can work together to form a single, gigantic and irresistible tidal wave" because "it is only this unity which will bring us to the realization of our dream: a Free Indonesia." Therefore, the idea of unity was one of the major themes of the political thought of Soekarno, and he was convinced that only with national unity, the goal of Indonesia's independence be achieved. His advocacy of unity was demonstrated by his statement: "I am not a Communist, I favor no side! I only favor unity - Indonesian Unity and friendship between all our different movements."

\section{PANCASILA}

The Explanation of Pancasila: Belief in one God (KeTuhanan Yang MahaEsa).Soekarno proclaimed about the belief in one God in June 1st 1945: “Arranging Indonesia independence with our devotion to one God. The principle of God. Indonesia is not only a country (that worships) God, but also every Indonesian should worship his own God. Let Christian worship God according to the direction of Isa al Masih. Let Muslim (worship) according to the direction of Nabi Muhammad SAW. Let Buddhist does his worship according to his own books. But let all of us (have) God. Let Indonesia country be the country that each person worships his own God with the most comfortable way. Let every citizen (has) God with culture, the culture without 'selfishness religion.' Let us do, be faithful to religion, either Muslim or Christian with a proper way. What is the proper way? Proper way is respect to one another."

Soekarno' speech clearly supported the diversity of religions in Indonesia. $\mathrm{He}$ embraced the diversity, and he encouraged Indonesian citizen to respect other beliefs. $\mathrm{He}$ is a supporter of religious freedom in Indonesia since Indonesia is multi-cultural, multi-ethnics and multi-religious country. Soerkarno' understanding of belief in one God is not monotheistic view. Instead, he sees that first principle as a country that is built and populated by people who have God. He expects that every citizen does according to his own religion and not to create a new conflict. In short, the belief in one God is not monotheistic view, but it is a nationality view that believes Indonesia is a country of people who worship God, and Indonesia embraces religions diversity.

The Purpose of Pancasila: BhinnekaTunggal Ika.The main concern that dominates Soekarno's mind is how to unite various trends of thought with their various values into a common concept of way of life without abolishing the healthy dynamics contained in each of them. From that point, he (Soekarno) builds his new frame of ideas by unifying the basic values of various trends of thought flourishing in his community into a coherent entity. Since the structure of Soekarno' idea reflects a living reality in his community, then 
it is thoughtful. Soekarno' ability to unify his community's basic values into a common, new way of life makes his ideas original. The crystallization of his ideas is expressed in his historic speech of June 1, 1945 on Pancasila.

Therefore, Pancasila does support religious freedom and plurality because it has a purpose to be united in diversity (bhinnekatunggalika).The Early History of Pancasila.Soekarno' speech was accepted by BPUKI (Badan Penyelidik UsahausahaPersiapan Kermendekaan Indonesia or Investigating Committee for Preparatory Work for Independence). On June 9th 1945, BPUKI made 'nine team'. The people are Soekarno, Muhammad Hatta, AA Maramis, AbikusnoTjokrosoejoso, AbdulkaharMuzakir, Agus Salim, Ahmad Soebardjo, Wahid Hasyim, dan Muhammad Yamin. On June 22nd 1945, they formulated the five principles from Soekarno and changed the order:

\section{1 .Lordship with obligation to do syariat Islam for its followers}

\section{A just and civilized humanism}

\section{Unity of Indonesia}

4. Democratic citizenship lead by wise guidance born of representative consultation

\section{Social just for all the people of Indonesia}

The debate between Islamic group and nationalist group for first principle continued because it could lead Indonesia to be an Islamic country. The word "syariat Islam" was defended by Ki BagoesHadikoesoemo because Islam played a role in Indonesia independence and Islam is the majority religion in Indonesia. These reasons were denied by Indonesian representation from East Indonesia because a certain religion cannot be a foundation of Indonesia.

Syariat Islam, then, was erased in the meeting of PPKI (Panitia Persiapan Kemerdekaan Indonesia) on August 18, 1945. Mohammad Hatta, the first vice President, defended this erasure. He argued that if those words were kept, then it will provoke other religions and Indonesia should embrace everyone. Historically, Indonesian leaders tried to maintain religious plurality by not accepting one religion to be a foundation of Indonesia.

\section{RELIGIOUS PLURALISM IN POSTMODERN ERA}

Pluralism holds that salvation (or enlightenment or liberation) should be acknowledged as present and effective in its own way in each religion. No single religion can claim to be somehow normative and superior to all others, for all religions are in their own way complex historically and culturally conditioned human responses to the one divine reality. Thus, although Christians can hold that Jesus is unique and normative for them, they cannot claim that Jesus is unique or normative in an objective or universal sense. In other words, all religions (or at least the "major" ones) are in their own ways complex historically and culturally conditioned human responses to the one ultimate Reality. Religious pluralist is someone with respect to a given issue when she claims not only (as a non-exclusivist) that no specific doctrinal perspective is superior but also makes the positive claim that the doctrinal perspectives of more than one basic theistic system or variant thereof are usually close to the truth. Some who claimed that the criteria of many different religious traditions are sufficient would be a religious pluralist.

\section{POSTMODERN ERA}

There are some factors that bring forth religious pluralism. This paper, however, will focus on the aspects of our Postmodern era such as globalization, relativism and secularization. As Netland says that postmodernity involves loss of optimism and confidence in human progress, incredulity toward metanarratives, skepticism, suspicion of claims to truth, exuberant celebration of diversity, relativism, pragmatism and pluralism.

Globalization. Globalization connects people from all around the world beyond geographical, national, ethnical, social, political and cultural boundaries. As a result, globalization promotes homogeneity and commonality in many aspects in the world. As Benjamin Barber states that even globalization promotes increased interconnectedness and 
commonalities across ethnic, religious, cultural and national boundaries, powerful countermodernizing reactions emphasize local distinctives opposed to the global. Globalization also transforms local cultural distinctives and causes the boundaries of the locals become vague. In regard to religious belief, people are bombarded with the information about other beliefs, and they might continue to maintain the same beliefs or practices, but they do so with the awareness that they must be situated in relation to the world "out there," with its alternative possibilities.

Globalization can undermine traditional certainties, raising doubt and a more tentative approach to knowledge or religious beliefs. For Westerners, globalization brings many beliefs from the East; people in the East, on the other hand, receive the spirit of tolerance, openness, and liberty. Thus, globalization works in both of group of people to promote religious pluralism in different ways.

\section{RELATIVISM.}

Relativism has been particularly attractive during the modern era. Allan Bloom, in his work on The Closing of the American Mind, provides says that there is one thing a professor can be absolutely certain of: almost every student entering the university believes, or says he believes, that truth is relative." Relativism does not deny the possibility of arriving at truth (indeed it assumes this), but it does deny that this "truth" is independent of particular contexts and applies to all people. Relativism comes in many forms and degrees, but at its heart is the claim that truth (or knowledge or rationality norms) is not unchanging or universally normative for all people but rather is relative to particular contexts. Relativism also promotes religious pluralism since there is no single religion is universally normative for all people. Secularization.Bryan Wilson, a proponent of traditional secularization thesis, states that secularization "relates essentially to a process of decline in religious activities, beliefs, ways of thinking, and institutions that occurs primarily in association with, or as unconscious or unintended consequences of, other processes of social structural change." Steve Bruce also defines secularization in three matters: the decline of popular involvement with churches; the decline in scope and influence of religious institutions; and the decline in popularity and influence of religious beliefs. The public sector becomes increasingly dominated by public secular institutions, with religious institutions, symbols and beliefs relegated to the private sphere. Since religion, in contrast to the hard sciences, does not enjoy any consensus concerning truth - witness the widely divergent truth claims made by the various religions and the lack of agreement as to how we might even settle such disputes - public expressions of religious belief are discouraged. In summary, secularization seems not to promote religious pluralism, but it does worsen exclusivists.

\section{PANCASILA AND RELIGIOUS PLURALISM}

Belief in God was formulated by Soekarno in recognition of the reality that the Indonesian people were religious, no matter to which religion they belonged. This principle seems to have been intended by Soekarno as an acknowledgement of all the religions existing in the country. Apparently, he thought that all religious groups could cooperate, and that religious tolerance could be achieved so that national unity and integrity would flourish in the atmosphere of an independent state. Pancasila, therefore, supports and respects religious freedom for Indonesian citizens. Pancasila is the relationship between Indonesia as a country with its individual citizen.

Religious pluralism, on the other hand, is the relationship between one religion to other religions. This distinction is so important. If someone holds religious pluralism, in nationalism context, Pancasila will support and respect his belief. Although Indonesia has been bombarded by globalization, relativism and secularization that promote religious pluralism, therefore a few people hold religious pluralism, most of Indonesian people still hold their own religions. There are a few reasons why most of Indonesian people (at least for now) do not hold religious pluralism: a) conflicting truth claims among these religions; b) religion, for Indonesian people, is an identity and our 
religions are mentioned in our ID card. Thus, it is a big deal when somebody changes his belief, because he can lose his family, job, friends and even his own life.

Although religious culture in Indonesia does not promote religious pluralism, we promote tolerance to other religions such as not saying negatively about other beliefs and practice because Pancasila embraces religious diversity.

\section{CONCLUSION}

Does Pancasila support religious pluralism in Indonesia in this Postmodern era? This is a complex issue. Pancasila indeed gives a religious liberty to its people. It is not Pancasila, but globalization, relativism, and secularism that gave birth and nurture religious pluralism in Indonesia in this Postmodern era. For now, the understanding of religions and Indonesian' culture (religion as identity) limit the growth of religious pluralism in Indonesia. It might be different in the future if globalization, relativism, and secularism really transform the mind of young generation and overcome Indonesian culture. When this happens, Pancasila seems to support and facilitate religious pluralism in Indonesia.

\section{REFERENCES}

\section{Book}

[1]. Alfian, Politik, Kebudayaan dan Manusia Indonesia. Jakarta: LP3ES, 1980.

[2]. Arthur, Chris. Religious Pluralism: A Metaphorical Approach. Aurora, Colorado: The Davies Group, 2000.

[3]. Barber, Benjamin.Jihad vs McWorld: How Globalization and Tribalism Are Reshaping the World. New York: Ballantine, 1996.

[4]. Basinger, David.Religious Diversity: A Philosophical Assessment. Ashgate Philosophy of Religion Series. Aldershot, Hants: Ashgate, 2002.
[5]. Bloom, Allan.The Crossing of the American Mind. New York: Simon \& Schuster, 1987.

[6]. Bruce, Steve.Religion in the Modern World: From Cathedrals to Cults. New York: Oxford University Press, 1996.

[7]. Carter, Stephen.The Culture of Disbelief: How American Law and Politics Trivialize Religious Devotion. New York: Basic, 1993.

[8]. Geertz, Hildred. "Indonesian Cultures and Communities," in Ruth T. Mcvey, ed., Indonesia. New Haven: Yale University Press, 1963.

[9]. Ismail, Faisal. "Islam, Politics and Ideology in Indonesia: A Study of the Process of Muslim Acceptance of the Pancasila." PhD Dissertation, 1995.

[10]. Moser, Paul K. Dwayne H. Mulder and J. D Trout, The Theory of Knowledge: A Thematic Introduction.New York: Oxford University Press, 1998.

[11]. Netland,Harold A. Encountering Religious Pluralism: The Challenge to Christian Faith \& Mission. Downers Grove, Ill.: InterVarsity Press, 2001.

[12]. Dissonant Voices: Religious Pluralism and the Question of Truth. Grand Rapids, Mich.: W.B. Eerdmans, 1991.

[13]. Neuhaus, Richard John.The Naked Public Square: Religion and Democracy in America. Grand Rapids, Michigan: Eerdmans, 1984.

[14]. Soekarno, Pancasila Sebagai Dasar Negara. Jakarta: Inti Idayu Press, Yayasan Pendidikan Soekarno, 1986.

[15]. Nationalism, Islam and Marxism. Trans. by Karel H. Warouw and Peter D. Weldon. Ithaca: Modern Indonesia Project. Cornell University, 1984.

[16]. Wilson, Bryan. "Secularization," in the Encyclopedia of Religion, ed. Mircea Eliade. New York: Macmillan, 1987. 
DIDASKALIA, VOLUME 2 NUMBER 2 OKTOBER 2019

\section{Website}

[17].https://www.infoplease.com/world/popula tion-statistics/worlds-50-most-populouscountries

[18].http://www.indonesia.cz/the-governmentof-the-republic-of-indonesia/

[19].https://www.thoughtco.com/sukarnoindonesias-first-president-195521

[20].https://news.detik.com/berita/d-

3222960/ini-pidato-bung-karno-1-juni-1945yang-jadi-cikal-bakal-lahirnya-pancasila. 